\title{
The Nonprofit Sector's 'Rich Relations'?
}

\section{Foundations and their grantmaking activities}

\author{
Tobias Jung \\ Centre for the Study of Philanthropy \& Public Good \\ School of Management, University of St Andrews
}

\section{Introduction}

As the number and resources of foundations, as well as their socio-political and economic importance, continue to grow globally (Johnson, 2018; Toepler, 2018), this chapter outlines and critically discusses the grantmaking foundation arena. The chapter highlights foundations' organisational characteristics, raises questions about the nature and portrayal of their grantmaking activities, considers the social and moral acceptability of foundations' resources, and points to wider issues relating to the roles, purposes and legitimacy of foundations. All of this, however, comes with a caveat. Namely, that the sphere of philanthropic foundations frequently appears akin to treacle: uncrystallised, partly refined, sickly sweet, sticky, slow-moving, messy.

The area seems uncrystallised in that it is a potpourri of ideas. Even foundations' own associations and umbrella bodies acknowledge that the term foundation has no precise meaning' (Association of Charitable Foundations, 2018; Council on Foundations, 2018). Confusions and imprecisions are commonplace. The area is partly refined in that although there is a large body of work on foundations from within the US, nuanced, international, understanding remains emergent. Here, the erroneous application and replication of US foundation labels - themselves tax law distinctions - across international contexts, as well as an overemphasis on a relatively small set of foundations that tend to be outliers rather than the norm - in relation to their resources, behaviour, and/or practices - have not been helpful. The field can appear both sweet and sickly in that reflective discourse has tended to be limited. Pleasantries and paranoia about foundations, glorifying and hypercritical perspectives, tend to go hand-in-hand (Jung \& Harrow, 2019). Foundation discourse also 
Jung, T, The Nonprofit Sector's 'Rich Relations'? Foundations and their grantmaking activities - to appear in Anheier, $\mathrm{H}$ and Toepler S (eds.) (2020, forthcoming), The Routledge Companion to Nonprofit Management, Routledge: London

appears somewhat sticky in that, historically, ideas seem to linger (Cunningham, 2016). The result is twofold. On the one hand, a diversity of labels can mask the same idea. Thus, the conceptual differences between scientific (Carnegie, 1901), strategic (Brown, 1979), high impact (Grace \& Wendroff, 2000), and entrepreneurial philanthropy (Gordon, Harvey, Shaw, \& Maclean, 2016) are debatable. On the other hand, the same labels seem to be repeatedly applied in reference to different ideas. Examples include the use and casting of 'creative philanthropy' (Anheier \& Leat, 2006 vs. Murphy, 1976), 'pragmatic philanthropy' (Shapiro, Mirchandani, \& Jang, 2018 vs. Thümler, 2017) and 'venture philanthropy' (Katz, 2005 vs. Stone, 1975). Finally, the field's velocity: while foundations are frequently seen as amongst the oldest institutional forms in the world, comparative and integrative research on foundations is a relatively recent area, an only slowly advancing one (Anheier, 2018; Toepler, 2018). Bearing all of this in mind, how can we understand the idea of a foundation?

\section{What is a foundation?}

Essentially, a foundation is an independent entity to which a donor transfers assets. This entity is then required to use those assets, and any associated returns, in pursuit of one or more defined purposes (Anheier \& Toepler, 1999; Goldsworth, 2016). In civil law systems, such as Germany, it is usually the case that such an entity is a specific, codified, legal structure. However, in common law systems, such as the UK, it is customary to use the foundation label in an uncodified manner to point to an entity's specific activities or to the public benefits it provides. Beyond this, things get conceptually and practically messy.

A foundation's donor can be an individual, a group, or a body from the private, public or nonprofit sector, or even a combination thereof. Assets can be of a financial or non-financial form, as well as permanent or transient. Depending on country-specific contexts, foundation purposes can be of a public but also of a private nature (European Foundation Centre, 2015). To achieve a foundation's purpose a variety of approaches can be used. These include those that are perceived as traditional and mainstream - operating or grantmaking - but, increasingly, can also take the form of social finance or the provision of prizes and awards (Frumkin, 2014; Salamon, 2014). While the latter are sometimes cast as representing the 'new frontiers' of philanthropy (Salamon, 2014), the extent to which they 
Jung, T, The Nonprofit Sector's 'Rich Relations'? Foundations and their grantmaking activities - to appear in Anheier, $\mathrm{H}$ and Toepler S (eds.) (2020, forthcoming), The Routledge Companion to Nonprofit Management, Routledge: London

are indeed novel developments warrants further exploration; their underlying ideas, principles and practices, as well as the challenges they present, appear relatively ancient with strong historical roots and precedents (e.g. Brealey, 2013; Schoon, 2015). Taken together, these diverse options and possible combinations mean that a multiplicity of ways in which foundations can be clustered, classified and categorised can be found in the literature (see Jung, Harrow, \& Leat, 2018).

\section{Operators and grantmakers}

Public, policy and academic debates are often dominated by the image of foundations as grantmakers; grantmaking is widely considered 'the core business of charitable foundations' (Orosz, 2004, p. 204). Both historically and contemporaneously, though, grantmaking foundations constitute a global minority. Operating foundations - those that design and carry out their own projects instead of funding others - have tended to, and do, prevail (Johnson, 2018; Toepler, 1999). As some of the most established foundation brands in the world - such as Carnegie and Rockefeller - originally favoured and begun with an operating model, the question arises as to why the grantmaking approach gained prominence (Leat, 2016).

Firstly, the emphasis on foundations' grantmaking appears to be an 'accident of history' (Leat, 2016, p. 299). While the operating approach offers the advantage of maintaining control over, and ownership of, a foundation's activities, it is also more costly, slower and inflexible compared to the grantmaking one (Frumkin, 2006). Following the emergence of the big US foundations at the beginning of the 20th century, such considerations gained in importance; these foundations' growth occurred alongside growing socio-economic needs and urgent political pressures for foundations to step up and assist (Leat, 2016). With US foundations also taking on increasingly prominent roles in shaping pre- and post-World War I and II policies and practices at national and international levels through grantmaking (Kiger, 2000; Parmar, 2012; Spero, 2010), their grantmaking approaches were globally transplanted and became seen as an essential foundation trait (Leat, 2016). 
Jung, T, The Nonprofit Sector's 'Rich Relations'? Foundations and their grantmaking activities - to appear in Anheier, $\mathrm{H}$ and Toepler S (eds.) (2020, forthcoming), The Routledge Companion to Nonprofit Management, Routledge: London

Secondly, with longstanding concerns about foundations' social and political activities, legitimacy and influence (Arnove, 1980; Heydemann \& Toepler, 2006; Krige \& Rausch, 2012; Roelofs, 2003), grantmaking also provides foundations with an organisational shield and safety buffer. Giving resources to an intermediary rather than carrying out your own programmes represents a shift in responsibilities: the onus for achieving a specific purpose passes to the grantee. Thereby, and as long as foundations operates within appropriate legal and accountability frameworks, they have limited direct answerability for the ways in which their grants are used by grantees and the outcomes they might - or might not achieve (Leat, 2016).

Finally, academia, policy and the media also appear to have played a role in raising awareness about, and emphasising, the grantmaking foundation model. As operating foundations undertake their own activities and programmes, they are difficult to separate from the wider field of nonprofit organisations (Toepler, 1999). In comparison, grantmaking foundations provide a more bounded field for researchers. Being more easily identifiable does, however, also mean that foundations readily attract the attention of policymakers looking for new and alternative funding sources (Harrow \& Jung, 2011), and that they offer an easy target for media in search of 'stories', with the result that missteps by one foundation quickly lead to problematic generalisations across the wider body of foundations (Gaul \& Borowski, 1993; Whitaker, 1974).

While the distinction between grantmaking and operating is a convenient shorthand, pure grantmaking foundations appear to be on the decline. With a wider move towards more engaged grantmaking approaches, outlined below, foundations increasingly combine grantmaking and operating approaches in their activities. What then constitutes grantmaking?

\section{Grantmaking}

At its most basic, grantmaking can be seen as 'awarding gifts of cash (grants)...in support of projects' (Orosz, 2004). It thus seems to be a reasonably straight forward activity: you pay somebody to do the work you are interested in. This, however, fails to acknowledge that 
Jung, T, The Nonprofit Sector's 'Rich Relations'? Foundations and their grantmaking activities - to appear in Anheier, $\mathrm{H}$ and Toepler S (eds.) (2020, forthcoming), The Routledge Companion to Nonprofit Management, Routledge: London

grantmaking can be 'a wearisome and complicated business' (Macdonald, 1956, p. 109). It masks that grantmaking is a highly diversified set of activities that incorporates numerous influences, traditions, styles, techniques and expressions across a range of stages: from establishing a grantmaking strategy, to developing appropriate decision-making procedures, protocols and practices, creating and promoting priorities and application guidelines, assessing and selecting ideas worthy of support, communicating decisions and conditions, managing active grants, evaluating results, making improvements, and addressing human temptations in the process (Association of Charitable Foundations, 2017; Cabinet Office, 2014b; DP Evaluation, 2012; Golden, 2004; Grant, 2016; Harrow \& Fitzmaurice, 2011; Orosz, 2004; Sprecher, Egger, \& von Schnurbein, 2016; Unwin, 2004). Thus, a large body of work providing guidance on grantmaking exists. Aspects that are emphasised include: focusing on those areas and approaches that are in line with the foundation's available resource base, having explicit funding criteria, offering accessible and user-friendly application forms and processes, using swift decision-making procedures and offering clear reasons for acceptances/rejections, and being honest and responsible in the grant terms, administration and conditions are managed (Grant, 2016, p. 415; Nielsen, 1985). These different facets of the grantmaking process present a range of issues to consider. These are outlined in Box 1.

Box 1 about here

The vocabulary that accompanies the resulting spectrum of grantmaking choices tends to be 'coarse and imprecise' (Nielsen, 1985, p. 420). For example, reference is being made to scientific rather than indiscriminate grantmaking, to pro-active rather than reactive approaches, to participatory rather than imposed grantmaking, to strategic or targeted grantmaking instead of 'scatteration', to conservative grantmaking for traditional areas such as philanthropic mainstays of education, health and culture, or to liberal grantmaking for reference to activities in more challenging areas such as social movements, controversial issues and urgent social problems (Nielsen, 1985, p. 420; Fleishman, 2007; Gibson, 2017; Meachen, 2010; Orosz, 2004; Prewitt, 2006a). The problem with such differentiations is that they tend to be value-laden and portmanteaux (Nielsen, 1985), and that the empirical and 
Jung, T, The Nonprofit Sector's 'Rich Relations'? Foundations and their grantmaking activities - to appear in Anheier, $\mathrm{H}$ and Toepler S (eds.) (2020, forthcoming), The Routledge Companion to Nonprofit Management, Routledge: London

theoretical underpinnings, as well as the practical applicability, of these labels is not always clear (Jung et al., 2018).

Within the context of grantmaking approaches, and responding to wider criticisms about the extent of philanthropy's actual achievements (e.g. Friedman, 2013; Goldberg, 2009; Singer, 2015), there has been a growing emphasis on maximising foundations' grantmaking efficiency and effectiveness (Nielsen, 1985; Sprecher et al., 2016). Promoted ideas include becoming a 'Total Impact' foundation, one that concentrates its resources on areas where it can achieve the largest impact (Cabinet Office, 2014a), using 'catalytic philanthropy' as a way to apply 'disruptive innovations and new tools' (Kramer, 2009), as well as conducting 'venture philanthropy', the application of venture capital and business models to the foundation world (John, 2006). These ideas have been accompanied by an industry geared towards encouraging, developing and measuring the impact and differences that foundations and other charities make (Inspiring Impact, 2017; National Committee for Responsive Philanthropy, 2009). The surrounding rhetoric and ideas seem, at least superficially, laudable and appealing. Whether or not more effective, efficient and impactful philanthropy should indeed be the overarching focus of grantmaking foundations needs, however, unpacking.

As already Henry Ford pointed out: 'charity and philanthropy are the repair shops and their efficiency, however high, does not remove the cause of human wrecks' (cited in Whitaker, 1974, p. 60). Thus, the extent to which foundations' approaches need to be re-thought more broadly arises (e.g. Thümler, 2017). It also means that, rather than simply dismissing and discarding traditional grantmaking approaches and treating them with disdain, it is worth reflecting whether, with their focus on 'gentle benevolence wrapped up in good intentions and support' and while a poor fit for the mushrooming emphasis on rationalism and audit cultures within the foundation field, traditional grantmaking might actually be more appropriate and 'relatively well adapted to the ambiguity, opportunism, and serendipity of foundation work' (Leat, 2017, p. 130). Thus, whether the drive for efficiency in grantmaking is of predominant benefit to philanthropy or plays to other interests, such as consultancy profits, political control or neoliberal agendas, and whether the surrounding 
Jung, T, The Nonprofit Sector's 'Rich Relations'? Foundations and their grantmaking activities - to appear in Anheier, $\mathrm{H}$ and Toepler S (eds.) (2020, forthcoming), The Routledge Companion to Nonprofit Management, Routledge: London

shift in discourse is beneficial or harmful to the field are other areas in need of further exploration (e.g. Leat, 2017; Scott, 2009; Thümler, 2016).

Foundations: rich relations?

Foundations are generally perceived as the nonprofit sector's 'rich relations' (Weissert \& Knott, 1995), as 'islands of money' (Smith, 2015). The robustness of these analogies is open for debate. Grantmaking foundations have a history of being reluctant to share data (Diaz, 2001). Being 'cautiously transparent', a substantial number of foundations prefers to keep information and data on their work private (OECD, 2018, p. 93). Within this context, the relative imbalance of research on foundations does not help. Although $60 \%$ of foundations identified in a recent global mapping are in Europe and only 35\% in North America (Johnson, 2018), most of the research on foundations comes from the US, with other countries, such as Canada, declaring the world of grantmaking foundations a 'terra incognita', uncharted territory (Rigillo, Rabinowitz-Bussell, Stuach, \& Lajevardi, 2018, p. 3). Thus, it is unsurprising that the mapping exercise concludes that surprisingly little is known about foundations' resources and the way these are used within, and across, national, regional and global settings: 'in much of the world, publicly available philanthropic data and knowledge are scarce' with insights being anecdotal, incomplete and even inconsistent (Johnson, 2018, p. 9).

To map the foundation world it is common practice to rank foundations by either their asset or grantmaking levels. The appropriateness of this approach has, however, been challenged. For example, foundations such as Stichting INGKA or Garfield Weston, whose main objectives appear to be acting as corporate shells, might be resource rich but could also be considered as philanthropic penny pinchers: their grantmaking levels appear relatively small when compared to their resources. The CEO of Germany's Association of Charitable Foundation Felix Oldenburg thus put it bluntly: in the absence of standard reporting systems, a lot of the work on foundations is 'ranking nonsense' with the only thing that we know for certain being that 'the Bill \& Melinda Gates Foundation is the world's largest foundation. That is pretty much it' (Oldenburg, 2018, NP; see also Grant, 2016). 
Jung, T, The Nonprofit Sector's 'Rich Relations'? Foundations and their grantmaking activities - to appear in Anheier, $\mathrm{H}$ and Toepler $\mathrm{S}$ (eds.) (2020, forthcoming), The Routledge Companion to Nonprofit Management, Routledge: London

At a global level, this lacuna of knowledge and patchwork quilt of information might be seen as a side-effect of the diverse socio-political and legal contexts within which foundations operate, or as arising from the divergent organisational expressions of the foundation form. However, even compiling data and information on grantmaking foundations at national levels remains problematic. This has repeatedly been highlighted by the authors of the one major ongoing survey of the UK's top-300 grantmaking foundations: data come from a variety of sources, are derived using a diversity of methods, and cover different timeframes (Pharoah, Walker, \& Goddard, 2017). The data that is available is also often quite dated. For example, at the point of writing, the latest available information on grantmaking foundations in the US offered by the Foundation Center (2018, NP), a self-described provider of 'the most comprehensive, reliable information about the social sector' and linked to the foundation field, is from 2014, i.e. at least four years old.

Acknowledging that the data and knowledge-base on grantmaking is thus not as good as one might hope for, what are the indicative insights that we do have? First of all, foundations appear to have global assets of around US\$1.5tn, of which $60 \%$ are held in the US and $37 \%$ in Europe, leaving 3\% of assets distributed across foundations in the rest of the world (Johnson, 2018). In light of these numbers and the geographic cluster in which these resources are distributed, critiques of foundations as instruments of cultural imperialism (Arnove, 1980) or as co-creators of world order (Krige \& Rausch, 2012) seem unsurprising. However, two things need to be borne in mind. First of all, compared to spending by government and by major players on the international development scene, foundation monies actually tend to be relatively meagre (OECD, 2018; Pharoah et al., 2017). Secondly, it is important to consider the way in which these resources are distributed across the foundation landscape.

Notwithstanding the above criticism of foundation rankings, looking at the ten richest foundations in the world provides some useful insights on how foundation assets are distributed. Here, the endowments of the Bill \& Melinda Gates Foundation, the Wellcome Trust or the Lilly Endowment - approximately US\$40n, US\$27bn and US\$10n respectively do indeed dwarf the Gross Domestic Product (GDP) of a number of countries. What this sample also highlights, however, is the relatively quick decline in foundations' assets at the 
Jung, T, The Nonprofit Sector's 'Rich Relations'? Foundations and their grantmaking activities - to appear in Anheier, $\mathrm{H}$ and Toepler S (eds.) (2020, forthcoming), The Routledge Companion to Nonprofit Management, Routledge: London

top-end. This is not restricted to global foundation rankings. It tends to be replicated at national levels too: a very small number of very large foundations is followed by an increasingly large number of smaller and smaller foundations. Accordingly, there are indications that globally $90 \%$ of foundations appear to have less than US\$10m, while $50 \%$ of foundations have actually less than US\$1m in assets (Johnson, 2018), a long way from the 'rich relative' analogy. Within the UK this 'long tail of philanthropy' means that 20 of the 300 top grantmaking foundations account for more than half of all the grants made (Pharoah, Jenkins, Goddard, \& Walker, 2016), while within the US the top 50 foundations are responsible for over a third (US\$20bn) of the total grantmaking of US\$60bn across the 87,000 foundations on the Foundation Center (2018) database. Independently of whether most foundations are thus actually 'rich relations', are they at least 'generous relations'?

Foundations: generous relations?

Foundations have repeatedly been criticised for being 'warehouses of wealth' (Gaul \& Borowski, 1993), for hoarding their resources rather than using them to the best of their abilities. In its current form, this criticism goes back to the beginning of the 20th century (Clotfelter, 1985). Perceived as tax management vehicles and as representing 'dangerous concentrations of unearned economic power' (Gaul \& Borowski, 1993), widespread calls for corrective legal actions have led to various reforms over the years, most prominently to the Tax Reform Act of 1969 in the US (Troyer, 2000). Notwithstanding that commentators questioned the Act's 'arbitrary rules', 'esoteric concepts', and ambition to imagine and close 'every possible loophole' for foundation abuse, independent of any compliance challenges and burdens (e.g. Worthy, 1975), the Act established a minimum payout requirement for foundations. Eventually fixed at $5 \%$, it raises interesting scenarios for reflecting on the philanthropic potential of the remaining resources. While qualifiers for foundations' minimum payout go beyond grantmaking and include administrative expenditures, such as employee compensation and office maintenance (for current payout regulations see Internal Revenue Service, 2018), the payout requirement and the level at which it is set remain strongly contested (Billitteri, 2005; Levine \& Sansing, 2014). 
Jung, T, The Nonprofit Sector's 'Rich Relations'? Foundations and their grantmaking activities - to appear in Anheier, $\mathrm{H}$ and Toepler S (eds.) (2020, forthcoming), The Routledge Companion to Nonprofit Management, Routledge: London

As any level of payout influences the extent to which an organisation that is reliant on its endowment can grow and thrive, central to the debate is whether foundations should exist in perpetuity or whether they should be expected to spend down (Steuerle, 1977). Those explicitly or implicitly in favour of foundations' perpetuity argue that increasing payout rates means to 'cut off the dog's tail an inch at a time' (Worthy, 1975, p. 254), it represents 'a slow but certain death sentence to foundations' (Robert Smith, Pew Memorial Trust, cited in Steuerle, 1977; also Hamilton, 2011). Over the last 17 years, this view has been reiterated in a series of studies funded by US foundations and their umbrella bodies. The recurring argument is that a $5 \%$ payout rate is 'somewhat too high' and 'challenging', with anything over and above $5 \%$ portrayed as leading to a certain depletion of resources with an eventual liquidation of foundations (Bignami, 2013; Cambridge Associates, 2000).

Not everyone in the foundation field shares this perspective. The US' National Network of Grantmakers, for example, has argued that 'it makes no sense to limit total payout to only 5\%' (Mehrling, 1999, p. 11); it has heavily criticised both foundations' obsession with investment banking at the expense of grantmaking, and the widespread tendency to equate and treat the required payout rate as a maximum level of giving (Mehrling, 1999). As the idea of spend out or limited lifespan foundations has gained traction, the last few years have seen wider support for this sentiment (e.g. Waleson, 2007).

Recent findings, cutting across grantmaking and operating foundations also indicate that there appear to be huge global variations in spending rates, ranging from $1.6 \%$ in Nigeria to $37 \%$ in Spain, with an average of $10.3 \%$ (Johnson, 2018). Even in the US, a number of foundations regularly exceeds the minimum payout requirement (Renz, 2012; Sansing \& Yetman, 2002) or, in countries where there a fixed legal payout requirement is absent, already make grants around the 5\% mark anyway (Pharoah et al., 2017). Thus, there are questions whether a variable payout rate, or even its abandonment altogether, might be appropriate (Deep \& Frumkin, 2001), or whether a minimum payout up to the point where foundations have made good on their received tax benefits should be required (Toepler, 2004). This then leads to the wider question about foundations. Where do their resources come from? What are the socio-political and economic roles that foundations play? What benefits do they provide, and to whom? 
Jung, T, The Nonprofit Sector's 'Rich Relations'? Foundations and their grantmaking activities - to appear in Anheier, $\mathrm{H}$ and Toepler S (eds.) (2020, forthcoming), The Routledge Companion to Nonprofit Management, Routledge: London

Are foundations' resources socially and morally acceptable?

From Andrew Carnegie to Bill Gates, from the pharmaceutical industry to tobacco, alcohol, oil and gas, the background of foundations' donors and resources, as well as the ways in which foundations invest and grow their assets can present various tensions. Are their resources socially and/or morally acceptable? As Francis Bacon (Bacon, 1886, p. 17) put it, 'glorious gifts and foundations are like sacrifices without salt; and but the painted sepulchres of alms'. Are foundations thus akin to an elaborate purification ritual for 'bitter money', money that is obtained through theft or harm (Tasimi \& Gelman, 2017)? Is it the case that ' $[\mathrm{t}] \mathrm{o}$ accept the reward of iniquity is to place upon our lips the seal of silence respecting its perpetrators' (Gladden, 1905, p. 23) when either the donor, his or her foundation, or the foundation's resources might be seen as 'tainted'?

While from an economic perspective money is considered to be fungible, i.e. it represents a unit of exchange whose history and physicality are insignificant, psychological research shows that money is often also construed in terms of its physical substance and material background: it can be contaminated by, and carries traces of, its moral history (Tasimi \& Gelman, 2017). As such, concerns about foundations' resources relate to a whole range of questions about un/acceptable funds. These include: issues of illegality and whether resources are a by-product of any harmful activities; whether grants come with 'strings attached' or violate moral codes; donors' own ethical stances and behaviours, and any 'sins' they might have committed in the past; concerns about 'guilt by association', the extent to which 'all private sector money is morally tainted', and if certain sources are simply inherently unacceptable (Jones, 2014).

Even if the original resources of a foundation might not present any moral, ethical or social challenges, the situation is further complicated by foundations' own investment strategies. Here, the view that higher investment returns translate into more resources for grantmaking, thus something to be desired, has tended to prevail across philanthropy. Questions about any negative social, political or economic impact of foundations' investment activities are rarely explored or reflected upon (Dowie, 2002), resulting in 
Jung, T, The Nonprofit Sector's 'Rich Relations'? Foundations and their grantmaking activities - to appear in Anheier, $\mathrm{H}$ and Toepler S (eds.) (2020, forthcoming), The Routledge Companion to Nonprofit Management, Routledge: London

situations where grantmakers' own investment of their resources can be diametrically opposed, and run counter, to their charitable activities (e.g. Mair, 2013). Where discussions about foundations' investment strategies do take place, the focus tends to be on short-term and narrow effects. Thus, while form an environmental and sustainability perspective the 'keep it in the ground' initiative by the British newspaper The Guardian and aimed at getting both the Bill \& Melinda Gates Foundation and Wellcome Trust to divest from fossil fuels (Randerson, 2015) might be positive, from a social welfare perspective, it also might have severe negative impacts on the communities whose jobs and infrastructures such disinvestment affects (e.g. Humphrey, Johnson, Lang, Roswell, \& Korn, 2014). This highlights the need for foundations and their critics to take a broader perspective and pursue strategies that go well beyond addressing immediate investment issues.

All these questions are of specific importance to grantees. Interestingly, and running counter to public discussions about acceptable funds, there are arguments that in relation to grants nonprofits are in a different moral zone than individuals (Morris, 2008). While individuals are perceived as being in a position to refuse gifts if the individual disapproves of its origin or originator, nonprofits may face more restricted moral, though not necessarily legally sanctioned, autonomy; their refusal of resources on moral grounds might be 'comparable to mismanagement in squandering scarce resources or tolerating other operational inefficiencies. In its quest for moral purity, the charity may be doing less good than it might' (Morris, 2008, p. 752). Indeed, there are indications that some charity trustees 'prioritise raising funds over upholding their personal values or ethics' that in their view 'all donations should be accepted irrespective of its provenance or the values of the donor organisations' (Harrow \& Pharoah, 2010, p. 6). Rather than reflecting on these issues in an abstract way, however, it is worth considering them within the context of foundations' roles more broadly.

\section{Foundations' roles and purposes}

Numerous castings of legitimacy can be identified. In relation to foundations, distinctions have been drawn between normative and procedural legitimacy (Heydemann \& Toepler, 2006) as well as between normative and empirical legitimacy (Harman, 2016), while in the 
Jung, T, The Nonprofit Sector's 'Rich Relations'? Foundations and their grantmaking activities - to appear in Anheier, $\mathrm{H}$ and Toepler S (eds.) (2020, forthcoming), The Routledge Companion to Nonprofit Management, Routledge: London

broader literature legitimacy has been cast as a threefold concept that incorporates conformity to established rules, those rules' reference to agreed and shared beliefs, and consent to the resulting power relations (Beetham, 2013). Taken together, these different ideas seem to provide a useful framework for exploring the legitimacy of foundations. First of all, normative legitimacy focuses on philosophical issues around the values and criteria that are, and should be, used to determine foundations' legitimacy per se. The second category, procedural legitimacy, looks at foundations' adherence to, and fulfilment of, legal frameworks, laws and socio-political contracts. Finally, empirical legitimacy addresses the social, political and economic perceptions of, and perspectives on, whether foundations are legitimate. While there have been longstanding debates about foundations' normative legitimacy (e.g. Reich, Cordelli, \& Bernholz, 2016) and the extent to which foundations live up to their promises (e.g. Thümler, 2011), the third aspect seems rarely to be challenged: despite widespread debates about foundations' governance, transparency and accountability, as well as prominent examples of scandals, corruptions and mismanagement, overall confidence in, support of, and ambitions for the foundation form seem strong (Anheier, 2018; Heydemann \& Toepler, 2006). To further explore questions of legitimacy, the actual roles, purposes and positioning of grantmaking foundations and their activities appear logical next steps (Heydemann \& Toepler, 2006).

What is the actual purpose of grantmaking as a practice (Leat, 2006a)? As the wife of a Ford Foundation executive reportedly asked: 'Why don't you boys just give everybody in the country two bucks apiece and quit?' (cited in Macdonald, 1956, p. 108). Indeed, while grantmaking offers 'a lifeline for a startlingly high number of academic research teams and fledgling non-profit organisations' (McGoey, 2015, p. 19), understanding of grantmaking foundations' actual roles and purposes has always been sketchy.

One challenge in trying to understand foundations' roles and contributions is the unresolved issue of whether foundations and/or their resources are of a public or a private nature. Both 'public' and 'private' are contested terms. They can relate to: legal and regulatory contexts of how organisations are differentiated into these two categories; the political context of whether foundations serve public or private interests; the economic context, that is if something is of collective or individual concern, and, finally; the social context, things that 
Jung, T, The Nonprofit Sector's 'Rich Relations'? Foundations and their grantmaking activities - to appear in Anheier, $\mathrm{H}$ and Toepler S (eds.) (2020, forthcoming), The Routledge Companion to Nonprofit Management, Routledge: London

are consequential or inconsequential for the public or an individual (Fernandez \& Hager, 2014). While traditionally foundations can be seen as, and consider themselves to be, private, that is distinct from public, governmental, organisations, and behave accordingly, at least under the political context perspective they are all public institutions too: 'their areas of engagement in society and justification for existence are outwardly focused' (Fernandez \& Hager, 2014, p. 431). This then makes them hybrids in the sense that foundations have simultaneously public and private claims (Fernandez \& Hager, 2014). This needs to be remembered when examining foundations' roles.

In their own words, grantmaking foundations do, and achieve, a lot of things. For example, the Mastercard Foundation (2018) 'catalyzes prosperity in developing countries', the Rockefeller Foundation (2018) is 'promoting the well-being of humanity throughout the world', and, as 'impatient optimists', the Bill \& Melinda Gates Foundation (2018) is 'working to reduce inequity'. Proactive and comforting, these slogans paint an encouraging picture. Notwithstanding grandiose rhetoric, being a grantmaking foundation in itself can, however, be seen as entirely and utterly unproductive: 'funds do nothing productive until they are transferred to a person or organisation that puts them to use' (Grant, 2016, p. 408). Grantmakers' only 'product' is 'an empty cheque book' (Leat, 1995, p. 323). Thus, more critical voices compare foundations to 'old-fashioned slot machines' in that 'they have one arm and are known for their occasional payout' (Viederman, 2011), to Don Quixotes in limousines - simultaneously comic and tragic characters fighting windmills - (Whitaker, 1974, p. 20), and to 'the cadaver at a family wake - their presence is essential, but not very much is expected of them' (foundation president cited in Emerson, 2004).

Synthesising the diverse imagery on US foundations, Mclllnay (1998) identifies six analogies for foundations' overarching roles that are perpetuated across foundation discourse. Accordingly, foundations can act as judges (of what and who gets funded, where and why), editors (fulfilling an intermediary function), citizens (having legal and voluntary responsibilities and obligations to others), activist (associated with the idea of social change and social movements), entrepreneur (innovators and risk takers) and partner (working with others across the private, public and nonprofit sector). While most of these images appear to be mythical rather than actual representations (Mcllnay, 1998), they do, however, 
Jung, T, The Nonprofit Sector's 'Rich Relations'? Foundations and their grantmaking activities - to appear in Anheier, $\mathrm{H}$ and Toepler S (eds.) (2020, forthcoming), The Routledge Companion to Nonprofit Management, Routledge: London

resonate with the growing body of work on foundations' socio-economic roles. Here, a number of overarching perspectives can be identified (Healy \& Donnelly-Cox, 2016; Toepler, 2017). Firstly, foundations are an expression of pluralism. They enable and allow the expression of a multitude of perspectives on what counts as public good and how this is provided and achieved. Secondly, they can fulfil a role in the voluntary redistribution of wealth. Thirdly, they can act as supplementary or substitutional funders in the provision of the public good or public services. Finally, due to their organisational independence and freedom - unrivalled by any other contemporary organisational form or institution (Anheier \& Leat, 2013) - they are seen as potential change agents and risk takers, as catalysts for innovation. The way these relationships between foundations and society play out has been cast as a partnership model, as a perfect match where both foundations and the state are reliant on each other to achieve the best outcomes (Macdonald \& Szanto, 2007), as a mismatch, where foundations are part of a 'shadow state' (Lipman, 2015) and an expression and enforcer of elite interests (McGoey, 2015), and as the institutional equivalent of a game of ping-pong, where foundations act as a prelude or postscript to public policy initiatives and state activities (Jung \& Harrow, 2019).

Closely related to questions of foundations' roles and activities, is the position that foundations assume vis-à-vis each other and in relation to different actors across the public, private and non-profit sectors (e.g. Förster, 2018; Mangold, 2018). Within this context, Anheier and Daly (2007, pp.17-20) refer to countries' regime types and draw on comparative data on foundations from the US and 18 European countries to point to six clusters of foundation-state relationships:

- Social democratic model - in a well-developed welfare state foundations complement or supplement state activities

- State-controlled model - foundations are subservient to, and closely controlled by, the state

- Corporatist model - foundations are subservient to the state and form part of the wider welfare system

- Liberal model - foundations co-exist in parallel and as a potential alternative to the state 
Jung, T, The Nonprofit Sector's 'Rich Relations'? Foundations and their grantmaking activities - to appear in Anheier, $\mathrm{H}$ and Toepler $\mathrm{S}$ (eds.) (2020, forthcoming), The Routledge Companion to Nonprofit Management, Routledge: London

- Peripheral model - foundations are insignificant, albeit worthwhile if refraining from challenging the status quo

- Business model - foundations are an expression of self-interest and aligned to corporate citizenship.

Alongside such explicit and public roles and positioning, foundations can also fulfil more private, implicit, functions. Akin to the organisational equivalent of a 'magic potion', their addressing of charitable issues can go hand-in-hand with solving business difficulties and family troubles (Lepaulle, 1927, p. 1126). Such functions are at their most noticeable in the history of those foundations with a family or industrial background. They include the use of foundations for managing tax issues, for maintaining family ownership and control of a corporate entity, as well as for enshrining a specific corporate vision or direction. Examples of such uses range from the establishment of the Ford Foundation in the US (Macdonald, 1956), to the Robertson Trust in Scotland (Maclean, 2001), Denmark's Carlsberg Foundation (2014), or the Stichting INGKA foundation in the Netherlands (Thomsen, 2017). Beyond this, foundations' structures and activities can also be used to keep the family happy: from grantee site visits offering entertainment opportunities for family members, to board meetings acting as family reunions (Oelberger, 2016).

While anathema to dominant contemporary perspectives on foundations, where they are at least implicitly seen to be linked to altruistic motives for wider good and where the use of foundations for personal benefits can be an abuse of the foundation form (e.g. Charity Commission for England and Wales, 2017), from historical, anthropological and sociological perspectives such private aims should not come as a surprise. Here, the practice and casting of gifts, altruism and egoism have not been considered as conceptual counterpoints but as symbiotic, as offering a win-win situation for private and public interests in philanthropic acts (Davis, 2000; von Reden, 2015).

\section{Concluding thoughts}

Given the complexities of the foundation field, there are ongoing questions about the actual and potential contributions that foundations can and could make in addressing and solving 
Jung, T, The Nonprofit Sector's 'Rich Relations'? Foundations and their grantmaking activities - to appear in Anheier, $\mathrm{H}$ and Toepler S (eds.) (2020, forthcoming), The Routledge Companion to Nonprofit Management, Routledge: London

social problems. In light of growing expectations of philanthropy more broadly, these appear particularly poignant. Here, their explicit track-record appears chequered. Exercising social control and maintaining social stability, as well as giving legitimacy to themselves and their partners sit alongside foundations' contributions to building social welfare, healthcare and education (Berman, 1983; Thümler, 2011). While this chapter has pointed to some of the key issues surrounding grantmaking foundations, other areas, such as power and donor voice, as well as wider debates about risk, have been left open (e.g. Grant, 2016; Orosz, 2004; Reich et al. 2016; Winkelstein \& Whelpton, 2017). As part of taking the foundation field forward, more nuanced perspectives are needed. Simplistic enchantments with, grandiose visions and claims of, as well as ambitions for, foundations need to be recast in more modest, realistic, terms (Anheier \& Leat, 2013; Harrow \& Jung, 2011). As foundations generally appear to be far from the 'rich relations' image, recent ideas encouraging foundations to be more pragmatic in their philanthropic endeavours by focusing on clearly bounded issues and niches (Thümler, 2017) appears promising. So, too, is the growing interest in more communal approaches to grantmaking by foundations. These try to move away from top-down, prescriptive, perspectives on what should be done towards more inclusive approaches to working with grantees. Examples from the UK include the Rank Foundation's engaged philanthropy approach, the Grants Plus programme advocated by the Esmée Fairbairn Foundation and others, as well as the John Ellerman Foundation's emphasis on being a 'responsive funder'; internationally, this trend is illustrated by the Rockefeller Foundation's ENGAGE initiative aimed at supporting networks, and the Case Foundation's 'Make it your own' awards programme. While still relatively emergent, they draw on traditional models of community philanthropy, social inclusion and community development and thus may offer a way to address some of the challenges highlighted in this chapter. 


\begin{tabular}{|c|c|}
\hline \multicolumn{2}{|c|}{ Box 1 - Key questions and issues that a grantmaking approach presents } \\
\hline $\begin{array}{l}\text { What are the } \\
\text { underlying drivers } \\
\text { for grantmaking? }\end{array}$ & $\begin{array}{l}\text { What type and degree of risk is the foundation willing to take? Is } \\
\text { the focus on alleviating symptoms or supporting the delivery of } \\
\text { services? } \\
\text { Is the aim to build or broker knowledge and understanding? } \\
\text { Is the aim to address root causes and work towards structural } \\
\text { and/or policy change? }\end{array}$ \\
\hline $\begin{array}{l}\text { What does the } \\
\text { foundation offer? }\end{array}$ & $\begin{array}{l}\text { What kind of support is being offered (financial or also non- } \\
\text { financial; direct or indirect)? } \\
\text { What type of costs will be supported (capital, revenue, project, } \\
\text { overheads, full, core)? } \\
\text { How much is being offered and when (small or large grants, at } \\
\text { which and for which part of the grantees' lifecycle)? } \\
\text { What shape does the funding take (restricted, unrestricted; gift, } \\
\text { grant, investment, prize, award; full, partial or matched)? }\end{array}$ \\
\hline $\begin{array}{l}\text { What is the funding } \\
\text { timeframe and } \\
\text { cycle? }\end{array}$ & $\begin{array}{l}\text { Is the focus on short- or long-term grants? } \\
\text { Is the emphasis on pro-cyclical (in line with the growth phase of an } \\
\text { economic cycle) or countercyclical (in line with economic decline, } \\
\text { challenges and recessions) grantmaking? }\end{array}$ \\
\hline $\begin{array}{l}\text { What is the theory } \\
\text { of change? }\end{array}$ & $\begin{array}{l}\text { To whom are resources offered (established or emergent } \\
\text { ideas/organisations)? } \\
\text { Is the focus on taking a top-down or a bottom-up approach? }\end{array}$ \\
\hline $\begin{array}{l}\text { What are the } \\
\text { characteristics of the } \\
\text { grant programme? }\end{array}$ & $\begin{array}{l}\text { Is it responsive and open so that anybody who meets the } \\
\text { foundation's criteria can apply? Is funding strategic and targeted } \\
\text { to a specific outcome? Is it by invitation only? }\end{array}$ \\
\hline Who benefits? & Explicitly? Implicitly? \\
\hline $\begin{array}{l}\text { What is the nature } \\
\text { of the foundation's } \\
\text { external } \\
\text { relationships? }\end{array}$ & $\begin{array}{l}\text { Is the relationship to grantees engaged or hands off? Direct or } \\
\text { through intermediaries? Is it a gift, contractual, auditing, } \\
\text { delegating or colloaritve relationship? } \\
\text { Does the foundation encourage and seek collaborations with } \\
\text { others or does it try to avoid them? } \\
\text { Is the foundation pursuing a high or a low external profile? }\end{array}$ \\
\hline & Leat, 2006b; Ridley, 2017; Unwin, 2004) \\
\hline
\end{tabular}


Jung, T, The Nonprofit Sector's 'Rich Relations'? Foundations and their grantmaking activities - to appear in Anheier, $\mathrm{H}$ and Toepler S (eds.) (2020, forthcoming), The Routledge Companion to Nonprofit Management, Routledge: London

\section{References}

Anheier, H., \& Leat, D. (2006). Creative Philanthropy. London: Routledge.

Anheier, H., \& Toepler, S. (Eds.). (1999). Private Funds, Public Purpose: Philanthropic Foundations in International Perspective. New York: Kluwer.

Anheier, H. K. (2018). Philanthropic Foundations in Cross-National Perspective: A Comparative Approach. American Behavioral Scientist, $O(0)$.

Anheier, H. K., \& Daly, S. (2007). The Politics of Foundations. London: Routledge.

Anheier, H. K., \& Leat, D. (2013). Philanthropic foundations: what rationales? Social Research, 80(2), 449-472.

Arnove, R. F. (Ed.) (1980). Philanthropy and Cultural Imperialism. The Foundations at Home and Abroad. Boston: G.K. Hall \& Co.

Association of Charitable Foundations. (2017). Introduction to Grant-Making Series. London.

Association of Charitable Foundations. (2018). What is a foundation? http://www.acf.org.uk/about/what-is-a-foundation/

Bacon, F. (1886). Of Riches. In E. A. Abbott (Ed.), Bacon's Essays (Vol. II). London: Longmans, Green and Co.

Beetham, D. (2013). The Legitimation of Power (2nd ed.). London: Palgrave Macmillan.

Berman, E. H. (1983). The Influence of the Carnegie, Ford and Rockefeller Foundations on American Foreign Policy: The Ideology of Philanthropy. Albany: State University of New York Press.

Bignami, P. G. (2013). Sustainable Payout for Foundations. 2013 Update Study: Cambridge Associates LLC.

Bill \& Melinda Gates Foundation. (2018). Homepage. https://www.gatesfoundation.org

Billitteri, T. J. (2005). Money, Mission, and the Payout Rule: In search of a strategic approach to foundation spending. Washington, DC: Aspen Institute.

Brealey, P. (2013). The Charitable Corporation for the Relief of Industrious Poor: Philanthropy, Profit and Sleaze in London, 1707-1733. History, 98(333), 708-729.

Brown, E. R. (1979). Rockefeller Medicine Men. Berkeley: University of California Press.

Cabinet Office. (2014a). How foundations are using Total Impact approaches to achieve their charitable mission. London:

https://www.gov.uk/government/uploads/system/uploads/attachment_data/file/38 6335/2903051_ImpactFoundations_acc.pdf

Cabinet Office. (2014b). Using a total impact approach to achieve social outcomes. https://www.gov.uk/government/publications/using-a-total-impact-approach-toachieve-social-outcomes

Cambridge Associates. (2000). Sustainable Payout for Foundations. Grand Haven, MI.

Carlsberg Foundation. (2014). Pursue Perfection. Copenhagen: Kontrapunkt.

Carnegie, A. (1901). The Gospel of Wealth and Other Timely Essays. New York: Century Co.

Charity Commission for England and Wales. (2017). Update on Cup Trust Inquiry.

Clotfelter, C. T. (1985). Foundations. In C. T. Clotfelter (Ed.), Federal Tax Policy and Charitable Giving (pp. 253-272). Chicago: University of Chicago Press.

Council on Foundations. (2018). What is a foundation? http://www.cof.org/content/foundation-basics\#what_is_a_foundation

Cunningham, H. (2016). The multi-layered history of Western philanthropy. In T. Jung, S. D. Phillips, \& J. Harrow (Eds.), The Routledge Companion to Philanthropy (pp. 42-55). London: Routledge.

Davis, N. Z. (2000). The Gift in Sixteenth-Century France. Oxford: Oxford University Press. 
Jung, T, The Nonprofit Sector's 'Rich Relations'? Foundations and their grantmaking activities - to appear in Anheier, $\mathrm{H}$ and Toepler S (eds.) (2020, forthcoming), The Routledge Companion to Nonprofit Management, Routledge: London

Deep, A., \& Frumkin, P. (2001). The Foundation Payout Puzzle. http://ksghauser.harvard.edu/index.php/content/download/68878/1248322/versio n/1/file/workingpaper_9.pdf

Diaz, W. A. (2001). The Lost Inner World of Grantmaking Foundations (or, as Willie Sutton once said, "That's Where the Money Is"). Nonprofit Management \& Leadership, 12(2), 213-218.

Dietz, N., McKeever, R., Steele, E., \& Steuerle, C. E. (2015). Foundation Grantmaking over the Economic Cycle. Washington: Urban Institute.

Dowie, M. (2002). American Foundations. An Investigative History. Cambridge MA: MIT Press.

DP Evaluation. (2012). A Funder Conundrum. Choices that funders face in bringing about positive social change. London:

Emerson, J. (2004). Reflections on Philanthropic Effectiveness. http://www.issuelab.org/resource/reflections_on_philanthropic_effectiveness

European Foundation Centre. (2015). Comparative Highlights of Foundation Laws. Brussels. Fernandez, K. M., \& Hager, M. A. (2014). Public and Private Dimensionns of Grantmaking Foundations. Public Administration Quarterly, 38(3), 405-439.

Fleishman, J. L. (2007). The Foundation. New York: Public Affairs.

Förster, S. (2018). Foundations in Germany: Social Welfare. American Behavioral Scientist Foundation Center. (2018). Foundation Stats. http://data.foundationcenter.org Friedman, E. (2013). Reinventing Philanthropy. Washington: Potomac Books.

Frumkin, P. (2006). Strategic Giving: the art and science of philanthropy. Chicago: Chicago University Press.

Frumkin, P. (2014). New Forms of Grantmaking: competitions, prizes and crowd sourcing. In L. M. Salamon (Ed.), New Frontiers of Philanthropy (pp. 514-535). Oxford: Oxford University Press.

Gaul, G. M., \& Borowski, N. A. (1993). Free Ride. The Tax-exempt Economy. Kansas City: Andrews and McMeel.

Gibson, C. M. (2017). Participatory Grantmaking: Has Its Time Come? : Ford Foundation. Gladden, W. (1905). The New Idolatry and other discussions. New York: McClure, Phillips \& Co.

Goldberg, S. H. (2009). Billions of Drops in Millions of Buckets. Hoboken: Wiley.

Golden, S. L. (2004). Grantseeking. In D. F. Burlingame (Ed.), Philanthropy in America: a comprehensive historical encyclopedia. (Vol. 1, pp. 209-211). Denver: ABC-Clio.

Goldsworth, J. G. (2016). Lexicon of Trust \& Foundation Practice. Huntingdon: Mulberry House Press.

Gordon, J., Harvey, C., Shaw, E., \& Maclean, M. (2016). Entrepreneurial philanthropy. In T. Jung, S. D. Phillips, \& J. Harrow (Eds.), The Routledge Companion to Philanthropy (pp. 334-347). London: Routledge.

Grace, K. S., \& Wendroff, A. L. (2000). High Ipact Philanthropy. London: John Wiley \& Sons. Grant, P. (2016). Directing and Managing Grantmaking. In T. Jung, S. Phillips, \& J. Harrow (Eds.), The Routledge Companion to Philanthropy (pp. 408-422). London: Routledge.

Hamilton, C. H. (2011). Payout Redux. Conversations on Philanthropy, VIII, 28-38.

Harman, S. (2016). The Bill and Melinda Gates Foundation and Legitimacy in Global Health Governance. Global Governance: A Review of Multilateralism and International Organizations, 22(3), 349-368. 
Jung, T, The Nonprofit Sector's 'Rich Relations'? Foundations and their grantmaking activities - to appear in Anheier, $\mathrm{H}$ and Toepler S (eds.) (2020, forthcoming), The Routledge Companion to Nonprofit Management, Routledge: London

Harrow, J., \& Fitzmaurice, J. (2011). The Art of Refusal: promising practice for grant makers and grant seekers. London: Centre for Charity Effectiveness, Cass Business School City University London.

Harrow, J., \& Jung, T. (2011). Philanthropy is dead; long live philanthropy? Public Management Review, 13(8), 1047-1056.

Harrow, J., \& Pharoah, C. (2010). How do you ask difficult questions? Shared challenges and practice amongst fundraisers and researcher. London:

Healy, J., \& Donnelly-Cox, G. (2016). The Evolving State Relationship: Implications of 'Big Societies' and Shrinking States. In T. Jung, S. D. Phillips, \& J. Harrow (Eds.), The Routledge Companion to Philanthropy. London: Routledge.

Heydemann, S., \& Toepler, S. (2006). Foundations and the Challenge of Legitimacy in Comparative Perspective. In K. Prewitt, M. Dogan, S. Heydemann, \& S. Toepler (Eds.), The Legitimacy of Philanthropic Foundations (pp. 3-26). New York: Russell Sage Foundation.

Humphrey, J., Johnson, B., Lang, K., Roswell, D., \& Korn, S. (2014). Fossil-Free Investment for a Just Appalachian Transition. Obstacles and Opportunities: Croatan Institute.

Inspiring Impact. (2017). Our vision. http://inspiringimpact.org/about/our-vision/ Internal Revenue Service. (2018). Tax on Private Foundation Failure to Distribute Income: "Distributable amount". https://www.irs.gov/charities-non-profits/privatefoundations/tax-on-private-foundation-failure-to-distribute-income-distributableamount

John, R. (2006). Venture Philanthropy: the evolution of high engagement philanthropy in Europe. Oxford: http://www.sbs.ox.ac.uk/sites/default/files/Skoll_Centre/Docs/Venture\%20philanth ropy\%20in\%20Europe.pdf

Johnson, P. D. (2018). Global Philanthropy Report: Hauser Institute for Civil Society and the Center for Public Leadership.

Jones, C. (2014). Dirty Money. Journal of Academic Ethics, 12, 191-207.

Jung, T., \& Harrow, J. (2019). Providing Foundations: philanthropy, global policy and administration. In D. Stone \& K. Moloney (Eds.), Oxford handbook on Global Public Policy and Transnational Administration (pp. 619-637). Oxford: Oxford University Press..

Jung, T., Harrow, J., \& Leat, D. (2018). Mapping Philanthropic Foundations' Characteristics: towards an international integrative framework of foundation types. Nonprofit and Voluntary Sector Quarterly, 47(5), 893-917

Katz, S. N. (2005). What Does It Mean to Say That Philanthropy Is "Effective"? The Philanthropists' New Clothes. Proceedings of the American Philosophical Society, 149(2), 123-131.

Kiger, J. C. (Ed.) (2000). Philanthropic Foundations in the Twentieth Century. Westport, CT: Greenwood Press.

Kramer, M. R. (2009). Catalytic Philanthropy. Standford Social Innovation Review, Fall, 3035.

Krige, J., \& Rausch, H. (Eds.). (2012). American Foundations and the Coproduction of World Order in the Twentieth Century. Göttingen: Vandenhoeck \& Ruprecht.

Leat, D. (1995). British foundations: the organisation and management of grant-making. VOLUNTAS: International Journal of Voluntary and Nonprofit Organizations, 6(3), 317-329. 
Jung, T, The Nonprofit Sector's 'Rich Relations'? Foundations and their grantmaking activities - to appear in Anheier, $\mathrm{H}$ and Toepler S (eds.) (2020, forthcoming), The Routledge Companion to Nonprofit Management, Routledge: London

Leat, D. (2006a). Grantmaking Foundations and Performance Measurement: Playing Pool? Public Policy and Administration, 21(3), 26-37.

Leat, D. (2006b). Grantmaking Foundations and Performance Measurement: Playing Pool? Public Policy and Administration, 21(3), 25-37.

Leat, D. (2016). Private and family foundations. In T. Jung, S. D. Phillips, \& J. Harrow (Eds.), The Routledge Companion to Philanthropy. London: Routledge.

Leat, D. (2017). Grantmaking in a Disorderly World: the limits of rationalism. Australian Journal of Public Administration, 77(1), 128-135.

Lepaulle, P. (1927). Civil Law Substitutes for Trusts. Yale Law Journal, 36(8), 1126-1147.

Levine, C. B., \& Sansing, R. C. (2014). The Private Foundation Minimum Distribution Requirement and Public Policy. Journal of the American Taxation Association, 36(1), 165-180.

Lipman, P. (2015). Capitalizing on crisis: venture philanthropy's colonial project to remake urban education. Critical Studies in Education, 56(2), 241-258.

Macdonald, D. (1956). The Ford Foundation. The Men and the Millions - an unauthorized biography. New York: Reynal \& Company.

Macdonald, G., \& Szanto, A. (2007). Private Philanthropy and Government: friends or foes? In S. U. Raymond \& M. B. Martin (Eds.), Mapping the New World of American Philanthropy - causes and consequences of the transfer of wealth (pp. 235-239). Hoboken: John Wiley.

Maclean, C. (2001). The Robertson Trust. Edinburgh: Maclean Dubois.

Mair, V. (2013, 10 Decemer). Comic Relief coverage highlights charities' investment dilemmas. Civil Society. https://www.civilsociety.co.uk/news/comic-relief-coveragehighlights-charities--investment-dilemmas.html

Mangold, J. (2018). Foundations in Germany: Higher Education. American Behavioral Scientist

Mastercard Foundation. (2018). About us. http://www.mastercardfdn.org/about/

McGoey, L. (2015). No such thing as a free gift. The Gates Foundation and the price of philanthropy. London: Verso.

Mclllnay, D. P. (1998). How Foundations Work: Jossey-Bass.

Mcllnay, D. P. (1998). How Foundations Work. San Francisco: Jossey-Bass.

Meachen, V. (2010). An Introductory Guide to Grantmaking. Melbourne: Philanthropy Australia.

Mehrling, P. (1999). Spending Policies for Foundations. The Case for increased grants payout. San Diego, CA: National Network of Grantmakers.

Morris, D. (2008). Tainted Money and Charity. Don 501(c)(3)s have a right to refuse a gift? Nonprofit and Voluntary Sector Quarterly, 37(4), 743-755.

Murphy, E. J. (1976). Creative Philanthropy. Carnegie Corporation and Africa 1953-1973. New York: Carnegie Corporation of New York.

National Committee for Responsive Philanthropy. (2009). Criteria for Philanthropy at Its Best. Washington: http://www.ncrp.org/wp-content/uploads/2016/10/paibfulldoc_lowres.pdf

Nielsen, W. A. (1985). The Golden Donors. A new Anatomy of the Great Foundations. New York: Truman Talley Books.

OECD. (2018). Private Philanthropy for Development. The Development Dimension. Paris: OECD Publishing. 
Jung, T, The Nonprofit Sector's 'Rich Relations'? Foundations and their grantmaking activities - to appear in Anheier, $\mathrm{H}$ and Toepler S (eds.) (2020, forthcoming), The Routledge Companion to Nonprofit Management, Routledge: London

Oelberger, C. R. (2016). Cui Bono? Private Goals in the Design of Public Organizations. Administration \& Society, Online First.

Oldenburg, F. (2018). Oldenburgs Impuls - Ranking Nonsense. https://www.stiftungen.org/stiftungen/blogs/stiftungsblog/ranking-nonsense.html

Orosz, J. J. (2004). Grantmaking. In D. F. Burlingame (Ed.), Philanthropy in America: a comprehensive historical encyclopedia (Vol. 1, pp. 204-209). Denver: ABC-Clio.

Parmar, I. (2012). Foundations of the American Century: The Ford, Carnegie, and Rockefeller Foundation in the Rise of American Power. New York: Columbia University Press.

Pharoah, C., Harrow, J., \& Jung, T. (2017). Examining payout in UK philanthropic foundations: Centre for Charitable Giving and Philanthropy.

Pharoah, C., Jenkins, R., Goddard, K., \& Walker, C. (2016). Giving Trends. Top 300 Foundation Grant-Makers. London: Association of Charitable Foundations.

Pharoah, C., Walker, C., \& Goddard, K. (2017). Giving Trends 2017. Top 300 Foundation Grantmakers. London: Association of Charitable Foundations.

Prewitt, K. (2006a). Foundations. In W. W. Powell \& R. Steinberg (Eds.), The Nonprofit Sector. A Research Handbook (2nd ed., pp. 355-377). New Haven: Yale University Press.

Randerson, J. (2015). A story of hope: the Guardian launches phase II of its climate change campaign. The Guardian.

https://www.theguardian.com/environment/2015/oct/05/a-story-of-hope-theguardian-launches-phase-two-of-its-climate-change-campaign

Reich, R., Cordelli, C., \& Bernholz, L. (2016). Philanthropy in Democratic Societies. Chicago: University of Chicago Press.

Renz, L. (2012). Understanding and Benchmarking Foundation Payout. New York: Foundation Center.

Ridley, S. (2017) Firm Foundations. Setting your grant-making strategy. Vol. 1. London: Association of Charitable Foundations, .

Rigillo, N., Rabinowitz-Bussell, M., Stuach, J., \& Lajevardi, N. (2018). Grantmaking in Canada and the United States: a comparative review and analysis of the literature. Montréal:

Rockefeller Foundation. (2018). Homepage. https://www.rockefellerfoundation.org

Roelofs, J. (2003). Foundations and Public Policy. The Mask of Pluralism. New York: State University of New York Press.

Salamon, L. M. (Ed.) (2014). New Frontiers of Philanthropy. Oxford: Oxford University Press.

Sansing, R., \& Yetman, R. (2002). Distribution Policies of Private Foundations. Hanover, NH: Tuck School of Business.

Schoon, N. (2015). Islamic finance as social finance. In A. Nicholls, R. Paton, \& J. Emerson (Eds.), Social Finance (pp. 572-588). Oxford: Oxford University Press.

Scott, J. (2009). The Politics of Venture Philanthropy in Charter School Policy and Advocacy. Educational Policy, 23(1), 106-136.

Shapiro, R. A., Mirchandani, M., \& Jang, H. (Eds.). (2018). Pragmatic Philanthropy. Asian Charity Explained. Singapore: Palgrave Macmillan.

Singer, P. (2015). The Most Good you can Do. Yale: Yale University Press.

Smith, B. (2015). Foundation Strategy...the Enemy of Collaboration? http://www.grantcraft.org/blog/foundation-strategy...the-enemy-of-collaboration

Spero, J. E. (2010). The Global Role of U.S. Foundations. New York: Foundation Center.

Sprecher, T., Egger, P., \& von Schnurbein, G. (2016). Swiss Foundation Code 2015: Helbing Lichtenhahn. 
Jung, T, The Nonprofit Sector's 'Rich Relations'? Foundations and their grantmaking activities - to appear in Anheier, $\mathrm{H}$ and Toepler S (eds.) (2020, forthcoming), The Routledge Companion to Nonprofit Management, Routledge: London

Steuerle, E. (1977). Pay-out requirements for foundations Research Papers sponsored by The Commission on Private Philanthropy and Public Needs (pp. 1663-1678). Washington: US Department of Treasury.

Stone, L. M. (1975). The Charitable Foundation: its governance. Law and Contemporary Problems, 39(4), 57-74.

Tasimi, A., \& Gelman, S. A. (2017). Dirty Money: The Role of Moral History in Economic Judgments. Cognitive Science, 41(S3), 523-544.

Thomsen, S. (2017). The Danish Industrial Foundations. Copenhagen: Djøf Publishing.

Thümler, E. (2011). Foundations, Schools and the State: school improvement partnerships in Germany and the US as legitimacy-generating arrangements. Public Management Review, 13(8), 1095-1116.

Thümler, E. (2016). Financialization of philanthropy: the case of social investment. In T. Jung, S. D. Phillips, \& J. Harrow (Eds.), The Routledge Companion to Philanthropy (pp. 362374). London: Routledge.

Thümler, E. (2017). Philanthropy in Practice: Pragmatism and the Impact of Philanthropic Action. London: Routledge.

Toepler, S. (1999). Operating in a grantmaking world: reassessing the role of operating foundations. In H. Anheier \& S. Toepler (Eds.), Private Funds, Public Purpose. Philanthropic Foundations in International Perspective (pp. 163-181). New York: Kluwer Academic.

Toepler, S. (2004). Ending Payout as we know it: a conceptua and comparative perspective on the payout requirement for foundations. Nonprofit and Voluntary Sector Quarterly, 33(4), 729-738.

Toepler, S. (2017). Public Philanthropic Partnerships: The Changing Nature of Government/Foundation Relationships in the US. International Journal of Public Administration, 1-13.

Toepler, S. (2018). Toward a Comparative Understanding of Foundations. American Behavioral Scientist, O(0), 0002764218773504.

Troyer, T. A. (2000). The 1969 Private Foundation Law: Historical Perspective on Its Origins and Underpinnings. The Exempt Organization Tax Review, 27(1), 52-65.

Unwin, J. (2004). The Grantmaking Tango: Issues for funders. London: The Baring Foundation.

Viederman, S. (2011). Foundations don't practice what they preach. http://www.marcgunther.com/stephen-viederman-foundations-dont-practice-whatthey-preach/

von Reden, S. (Ed.) (2015). Stiftungen zwischen Politik und Wirtschaft. Oldenburg: DeGruyter.

Waleson, H. (2007). Beyond Five Percent: the new foundation payout menu. San Francisco, CA and New York, NY: Northern California Grantmakers and New York Regional Association of Grantmakers.

Weissert, C. S., \& Knott, J. H. (1995). Foundations' impact on policymaking: results from a pilot study. Health Affairs, 14, 275-286.

Whitaker, B. (1974). The Foundations. An Anatomy of Philanthropy and Society. London: Eyre Methuen.

Winkelstein, M., \& Whelpton, S. (2017). Foundations Don't Know What They Are Risking. The Foundation Review, 9(2), 93-108. 
Jung, T, The Nonprofit Sector's 'Rich Relations'? Foundations and their grantmaking activities - to appear in Anheier, $\mathrm{H}$ and Toepler S (eds.) (2020, forthcoming), The Routledge Companion to Nonprofit Management, Routledge: London

Worthy, M. K. (1975). The Tax Reform Act of 1969: consequences for private foundations. Law and Contemporary Problems, 39(4), 232-254. 